Maria das Dores Campos Machado

\title{
Aborto e ativismo religioso nas eleições de 2010
}

Este artigo analisa a participação de atores religiosos individuais e coletivos no processo eleitoral realizado no Brasil em 2010 para a escolha do Presidente da República e representantes das unidades federativas na Câmara Federal ${ }^{1}$. Marcado não só pela eleição da primeira mulher a ocupar o cargo político mais importante do país, esse pleito expressou tendências importantes em curso na sociedade, como, por exemplo, o uso das mais novas tecnologias digitais pelos atores religiosos individuais que disputavam tanto o poder executivo quanto as cadeiras para o legislativo e pelos movimentos confessionais de caráter tradicionalista para inclusão dos temas do aborto e da homossexualidade no debate eleitoral. Numa disputa em que se apresentaram nove candidatos para o posto mais importante da política nacional e em que, as duas candidaturas femininas receberam mais de $66 \%$ dos votos para a Presidência da República no primeiro turno das eleições², líderes religiosos atuaram intensamente para manter a política institucional nos marcos ideológicos cristãos.

Nesse sentido, parte-se da perspectiva que interpreta os coletivos religiosos não como resquícios de um passado pré-moderno, mas sim como atores políticos atuando nas muitas modernidades existentes na contemporanei-

Agradeço ao CNPq o apoio financeiro concedido através da Bolsa de Produtividade em Pesquisa.

2 Dos 101,6 milhões de votos válidos, 47,7 milhões foram para Dilma Rousseff, 19,6 milhões para Marina Silva, 33,1 milhões para José Serra e o restante distribuído entre seis outros candidatos de partidos pequenos. 
dade $^{3}$ e não raras vezes, atendendo aos chamados de movimentos sociais, de partidos políticos ou mesmo do próprio Estado ${ }^{4}$. De modo que não se pretende aqui questionar a legitimidade da participação dos grupos religiosos na esfera pública, mas sim apontar para os riscos da falta de regulação dessa participação na política institucional para a laicidade do Estado e para a ampliação dos direitos humanos e, em particular, a inclusão das demandas dos movimentos sociais nos marcos desses direitos.

Com intuito de examinar as ações coletivas e individuais dos atores religiosos nesse contexto de competição pelo executivo e legislativo, o artigo foi organizado em três sessões, iniciando-se pela análise das manobras realizadas pelos grupos conservadores da Igreja Católica e dos segmentos evangélicos para interferir na disputa presidencial. Em seguida, examinarei as campanhas eleitorais de candidatos oriundos do campo religioso à Câmara Federal na webesfera e a importância da dimensão religiosa nas biografias e performances políticas desses atores individuais. Na terceira sessão e à guisa de conclusão, procuro estabelecer as conexões entre os projetos políticos individuais e coletivos e demonstrar o caráter reativo do "ativismo religioso conservador" em relação aos avanços dos movimentos no campo feminista e da diversidade sexual no país.

\section{A competição religiosa e político-partidária no Brasil}

As últimas três décadas na sociedade brasileira foram marcadas não só pela retomada da democracia como também pelo acirramento da competição no interior do campo religioso e pela crescente participação dos segmentos evangélicos pentecostais na política partidária e nas disputas eleitorais. Reflexo do declínio contínuo do número de católicos ${ }^{6}$ e da correlacionada difusão

\footnotetext{
Ver Eisenstad (2001); Berger et al. (2008); Habermas (2007) entre outros.

4 Basta mencionar a parceria estabelecida em 2009 entre o Ministério da Saúde e a Conferência Nacional dos Bispos do Brasil para a realização de Campanha para o Diagnóstico Precoce da AIDS. A parceria foi assinada no dia 23 de outubro e amplamente divulgada na mídia secular e católica. Ver, por exemplo, o Jornal O Globo de outubro de 2009.

Segundo Vaggione (2010, p. 15), o termo ativismo conservador"permite enfatizar o propósito central, que é o de influenciar as políticas públicas e as legislações. São setores que não só defendem uma cosmovisão específica sobre a sexualidade e a família que se encontraria ameaçada pelo feminismo e pela diversidade sexual, como também se mobilizam ativamente para fazer com que o direito e as políticas públicas sigam essa cosmovisão".

6 Os católicos representavam 89,2\% em 1980, passaram a ser 83,3\% da população em 1991 e 73,3\% em 2000. Nesse mesmo período, os evangélicos que representavam 6,6\% dos brasileiros em 1980 passaram para 9,0\% em 1991 e 15,4\% em 2000.
} 
das igrejas pentecostais nos setores médios e pobres da população brasileira, a inserção crescente dos atores na política partidária veio acompanhada da criação no interior das estruturas eclesiásticas do campo evangélico de instâncias de formação de lideranças que pudessem defender os interesses das igrejas nas casas legislativas e junto às esferas do poder executivo nos governos municipais, estaduais e federal. Numa disputa por fiéis, que é ao mesmo tempo exógena e endógena, os grupos evangélicos acabaram por encontrar na via da política partidária uma forma de combater as prerrogativas históricas da Igreja Católica (no campo da educação, da saúde, da assistência social, na concessão dos meios de comunicação, etc.) e ampliar sua capacidade de influência na sociedade brasileira.

Uma das consequências interessantes dessa tentativa de se fortalecer nas sociedades civil e política foi o deslocamento de certos grupos pentecostais da oposição ao Partido dos Trabalhadores (PT) para o papel de aliados políticos de Lula e seus correligionários nas eleições de 2002, durante os dois governos petistas $^{7}$ e no pleito de 2010. Assim, enquanto as lideranças da Assembleia de Deus, maior grupo pentecostal do Brasil, se dividiram no primeiro turno das últimas eleições presidenciais entre as candidaturas de Marina Silva, pelo Partido Verde (PV), de Dilma Rousseff, pelo PT, e de José Serra, pelo Partido Social Democrata do Brasil (PSDB), líderes da Igreja Universal do Reino de Deus engajaram-se na campanha petista e travaram duros embates com seus pares pentecostais nas mídias eletrônica, impressa e digital para desconstruir a associação da candidata Dilma com os temas polêmicos da descriminalização do aborto e da união civil de pessoas do mesmo sexo.

No espectro católico, enquanto os grupos progressistas, que tiveram um papel importante na fundação e consolidação do PT, decepcionados com o envolvimento de integrantes dessa agremiação partidária em escândalos econômicos do primeiro governo Lula (2003-2006), começaram um processo de migração para partidos mais à esquerda ${ }^{8}$, os movimentos de Renovação Carismática, Opus Dei e Defesa da Vida intensificaram os ataques ao partido e seus representantes, associando-os com os valores não cristãos. E foram justamente esses segmentos que engrossaram o movimento encabeçado por bispos e padres conservadores de combate à candidatura de Dilma Rousseff,

Ver Machado (2006) e Oro (2002).

8 Em 2005 foi criado o Partido Socialismo e Liberdade (PSOL), que atraiu parcela dos descontentes com o rumo do governo petista. 
que antes do período eleitoral declarara à imprensa em mais de uma ocasião ser favorável à descriminalização do aborto 9 .

Ainda que a apreensão dos atores religiosos cristãos com o tema do aborto não seja propriamente uma novidade, as inciativas dos dois governos Lula de instalar uma Comissão Tripartite de Revisão da Legislação Punitiva sobre o Aborto (2005), a realização da Audiência Pública sobre o Aborto, em 27 de junho de 2007, e o lançamento de um novo Programa Nacional de Direitos Humanos (PNDH-3), em dezembro de 2009, parecem ter amplificado a reação coletiva dos segmentos tradicionalistas. Concentraremos o nosso exame nessa última iniciativa, pois ela tentava de alguma forma incorporar propostas oriundas dos debates anteriores.

O primeiro ponto a se destacar é que o $\mathrm{PNDH} 3$ foi precedido pelo $\mathrm{PNDH}$ 1 (1996), que enfatizou os direitos civis e políticos, e pelo PNDH-2 (2002), "que incorporou os direitos econômicos, sociais, culturais e ambientais". Subscrito por trinta e um ministérios diferentes, o PNDH3 aborda distintos e controversos temas ${ }^{10}$ como: a descriminalização do aborto; a criação de uma Comissão da Verdade para investigar os crimes cometidos na ditadura militar, a criação de redes de proteção dos Direitos Humanos de lésbicas, gays, bissexuais, travestis e transexuais; a regulação governamental dos meios de comunicação tendo como ponto de referência os direitos humanos, etc. Diferentes segmentos sociais reagiram de forma negativa ao programa militares, fazendeiros, empresários, etc. - , mas nos interessa sublinhar aqui

\footnotetext{
Em 2007, quando ocupava o cargo de ministra-chefe da Casa Civil, Dilma afirmou em sabatina no jornal Folha de São Paulo que era um "absurdo" que o Brasil não houvesse descriminalizado o aborto. Em maio de 2010, entrevistada pela revista Isto É, Dilma afirmou: "Eu acho que, o aborto, do ponto de vista de um governo não é uma questão de foro íntimo, é uma questão de saúde pública. E que você não pode hoje segregar mulheres e deixar que certos métodos, que hoje são encontrados na população de mais baixa renda, você vê uma porção de gente, principalmente nos grupos de mulheres você vê essa conversa muito forte... O uso da tal das agulhas de tricô, aquelas compridas, o uso de chás absurdos, o uso de métodos absolutamente medievais... Enquanto isso segmentos, há uma certa falsidade social, que as mulheres de mais alta renda vão para hospitais, clínicas privadas ou qualquer coisa assim e lá fazem o aborto. Então acho que, do ponto de vista de um governo, não é uma questão e não pode ser tratada como questão de foro íntimo. É uma questão necessariamente de saúde pública e tem de ser seriamente conduzida desse jeito". Ver em http://www.istoe.com.br/ reportagens/71512_NOS+FIZEMOS+E+SABEMOS+COMO+CONTINUAR+A+FAZER+PARTE+2.

10 Segundo o dossiê publicado pela Casa de Política, o PNDH-3 tem "6 eixos orientadores, subdivididos em 25 diretrizes, 82 objetivos estratégicos e 521 ações programáticas). Os seis eixos orientadores são: I) Interação democrática entre Estado e sociedade civil; II) Desenvolvimento e Direitos Humanos; III) Universalização de direitos em contexto de desigualdades; IV) Segurança Pública, Acesso à Justiça e Combate à Violência; V) Educação e Cultura em Direitos Humanos; VI) Direito à Memória e à Verdade." http://casadepolitica.blogspot.com/2010/01/dossie-pndh-3.html
} 
os impactos dessa iniciativa nos grupos religiosos. Nesse sentido, pode se afirmar que apresentação do aborto como um tema de saúde pública e a proposta de revisão da legislação existente com intuito de garantir o acesso das mulheres aos serviços de saúde amplificou a tensão já existente entre os coletivos religiosos tradicionalistas e o governo, provocando uma grande polêmica na esfera pública poucos meses antes de ter início o período eleitoral.

Como alertou-nos Boaventura de Souza Santos (2009), a relação entre os discursos religiosos e o dos direitos humanos é muito complexa e pode variar em função das tradições religiosas e da conjuntura política. Isto se deve em parte pela heterogeneidade dos discursos no interior das próprias tradições religiosas e em parte pela pluralização e a ampliação das zonas de contatos entre as diferentes comunidades confessionais e entre estas e a perspectiva dos direitos humanos que tem servido de balizas para a atuação do Estado liberal.

De qualquer maneira, na perspectiva dos direitos humanos, a religião tem a ver com a esfera do compromisso privado e é matéria de um dos diferentes direitos do homem: o direito à liberdade religiosa. Situação que não só favorece a multiplicação das denominações confessionais, como também abre brechas para diálogos e tensões entre estas duas perspectivas. Em algumas áreas temáticas, como a da desigualdade econômica e a da fome, o diálogo e mesmo a incorporação dos princípios dos direitos humanos nos discursos religiosos parecem mais fáceis. O engajamento de setores evangélicos e católicos na luta contra a ditadura militar no Brasil e a atuação dos grupos ligados à Teologia da Libertação e às comunidades Eclesiais de Base exemplificam bem esse diálogo. Contudo, existem áreas temáticas importantes, como a da moral sexual e a do controle da fertilidade feminina, nas quais os princípios dos direitos humanos enfrentam maior dificuldade de penetrar.

Há décadas as feministas denunciam o papel das instituições religiosas na perpetuação das normas, estereótipos e das atitudes sociais que legitimam a desigualdade de gênero. E mesmo que se reconheça o esforço de alguns segmentos no desenvolvimento de discursos religiosos contra-hegemônicos que dialoguem com a perspectiva dos direitos humanos, como o do grupo denominado Católicas pelo Direito de Decidir, o impacto desses discursos na regulação jurídica e política das relações de gênero parece bastante reduzido diante do ativismo religioso dos movimentos confessionais tradicionalistas. Enfatizando o direito da liberdade de crença e das minorias religiosas se ex- 
pressarem, tais grupos desafiam os movimentos sociais que também viram na linguagem dos direitos individuais uma possibilidade de lutar contra as discriminações impostas às mulheres, aos homossexuais, lésbicas etc.

Nos últimos anos ocorreu uma série de embates entre militantes dos movimentos feminista e LGBT e ativistas religiosos em torno do sentido da vida e da percepção da sexualidade humana, assim como da regulação jurídica das pesquisas com células-tronco, interrupção da gravidez em casos de anencefalia fetal, das relações homoafetivas, da criminalização das formas de discriminação dos não heterossexuais, entre outros. Embates que vem ocorrendo não só no judiciário como também no poder legislativo, com apresentação de projetos de leis de ambos os lados (Avila, Portella e Ferreira, 2005; Duarte et al., 2009).

No caso específico do Programa Nacional dos Direitos Humanos, a reação foi forte, tanto do lado católico quanto do evangélico, embora se perceba que entre esses, para além do aborto, a tentativa de criminalizar a discriminação com base na orientação sexual gerou muita controvérsia entre os pastores, os militantes dos movimentos sociais e os responsáveis pela elaboração do programa. Em virtude da forte pressão das igrejas, a proposta original foi revista, mas as modificações não foram suficientes para eliminar as desconfianças dos grupos confessionais em relação ao PT e à sua futura candidata. Tentando atenuar a reação dos tradicionalistas, Dilma visitou igrejas e lançou, assim que começou o período de propaganda eleitoral, um documento chamado "Carta aberta ao povo de Deus", no qual, além de reconhecer a importância do trabalho das igrejas evangélicas na sociedade brasileira, assumiria o compromisso de deixar para o Congresso Nacional

a função básica de encontrar o ponto de equilíbrio nas posições que envolvem valores éticos e fundamentais, muitas vezes contraditórios, como aborto, formação familiar, uniões estáveis e outros temas relevantes tanto para as minorias como para a sociedade brasileira.

Essa mensagem foi postada no site da candidata ${ }^{11}$ e replicada em mídias digitais evangélicas de diferentes grupos denominacionais e de atores individuais. De qualquer maneira chamava atenção o apoio à candidatura petista, desde o início do período eleitoral, do Pastor Manuel Ferreira da 
Convenção das Igrejas Assembleia de Deus de Madureira e do Pastor da Igreja Batista Renovada e Senador da república Magno Malta, ambos situados no espectro mais tradicional do evangelismo brasileiro, enquanto no espectro neopentecostal o suporte vinha dos dirigentes das igrejas Sara Nossa Terra e da Universal do Reino de Deus (IURD), em especial do bispo e ex-deputado Federal Robson Rodovalho e líder da Igreja Sara Nossa Terra, e de Marcelo Crivella, senador da república e bispo licenciado da IURD. Alguns desses líderes tiveram seus retratos inseridos no material de propaganda impressa ou gravaram declarações de adesão à campanha de Dilma.

A posição mais ousada na defesa da candidatura petista viria, entretanto, do fundador da IURD e hoje proprietário do terceiro canal de televisão do país: o bispo Edir Macedo que desde a década de 90 vem utilizando a sua mídia impressa e eletrônica para divulgar sua posição mais liberal em relação à temática do aborto (Machado, 2000; Gomes e Menezes, 2008; Gomes, 2009). Parte do material difundido na internet, principalmente os vídeos postados no YouTube, resulta de uma exposição desse líder neopentecostal à Associação das Mulheres Cristãs, bem antes do período eleitoral e que foi transformada em um DVD para ser vendido em supermercados e em bancas de jornal. Em março de 2010 surgiram as primeiras matérias na mídia acerca da venda do DVD “O Segredo do Sucesso" com a reprodução da pregação de Edir Macedo. Mais do que o expediente para difundir suas ideias, interessa-me aqui explorar a posição daquele que, assumindo ser filho de uma mulher que interrompeu 16 gestações ${ }^{12}$, usou o tema do aborto para se aproximar ainda mais do núcleo petista que ocupa o poder político no país. Segundo suas palavras, ele gosta de falar do tema do aborto,

não para contrariar a Igreja Católica, mas para ajudar as pessoas a levar uma vida de melhor qualidade, de menos violência, menos morte, menos mortalidade infantil, menos doença. Enfim, menos desse mal que temos visto em nossa sociedade [...]. O que é melhor: um aborto ou uma criança mendigando na rua ou vivendo no lixão? O que é melhor? [...] É preferível o aborto [...] A Bíblia fala que é melhor a pessoa não ter nascido do que viver no inferno. ${ }^{13}$

\footnotetext{
${ }_{12}$ Ver http://www1.folha.uol.com.br/poder/807505-dilma-diz-que-nao-mudou-de-ideia-sobre-aborto. shtml

${ }^{13}$ YouTube - Bispo Evangélico Edir Macedo defende o aborto como forma de Planejamento Familiar. http://www.youtube.com/watch?v=4uWSuc1 fvNk.
} 
Empregando várias vezes a palavra aborto seguida da categoria planejamento familiar, como se as duas fossem sinônimas, esse líder religioso foi uma peça importante no tabuleiro de xadrez da competição, não só pelos votos evangélicos que no primeiro turno das eleições presidenciais teriam sido direcionados à Marina Silva, mas também para estancar a campanha contra a Dilma entre os pentecostais. Ainda que com um discurso de caráter essencialmente pragmático que associa a interrupção da gravidez com o combate à miséria, a criminalidade e "ao mal da sociedade", e não ao direito de livre escolha das mulheres, tão caro às feministas, esse ator religioso expressava um contraponto aos segmentos mais tradicionalistas e foi um aliado político importante junto às camadas populares. Tachado de "advogado do capeta" por seus desafetos, o bispo da Igreja Universal foi recompensado ainda durante o período eleitoral com a inclusão de sua emissora de TV, a Rede Record de Comunicações, entre os meios de comunicação que realizariam debates com as principais candidaturas ao cargo da Presidência da República, e posteriormente com o convite para participar da cerimônia de posse de Dilma Rousseff.

É importante registrar que Marina Silva, "obreira” da Assembleia de Deus $^{14}$, e com posições pessoais mais tradicionalistas em relação ao aborto e as relações homoafetivas, disputou as eleições por um partido político que historicamente tem posições mais liberais com relação aos dois temas ${ }^{15}$. Essa dualidade gerou muita desconfiança tanto na liderança religiosa tradicionalista quanto na base do PV e acabou por levar a candidata a adotar a estratégia de transferir para a população brasileira a responsabilidade de definir o encaminhamento dessas questões através de um plebiscito. Com essa posição, a candidata, que construiu sua trajetória política no Partido dos Trabalhadores e foi ministra do governo Lula, acabaria se beneficiando do grande embate entre os líderes evangélicos e a candidata petista durante o primeiro turno das eleições. Sinteticamente, o crescimento da candidatura de Marina entre os seus irmãos de fé na reta final desse turno, resultou muito mais dos ataques dos líderes evangélicos ao $\mathrm{PNDH} 3$ e às posições do $\mathrm{PT}$ e da própria Dilma Rousseff em relação ao tema do aborto do que ao engajamento de um número significativo de pastores e missionários na sua campanha.

\footnotetext{
${ }^{4}$ Segundo os dados do Censo Nacional realizado pelo IBGE, essa denominação tinha mais de 8 milhões de fiéis em 2000.

${ }^{15}$ Embora tenha uma agenda política mais liberal, o Partido Verde alterou seu estatuto quando da entrada de Marina Silva e passou a permitir que seus integrantes seguissem sua consciência nos casos de conflito ético entre as posições partidárias e pessoais.
} 
Embora seja uma pessoa extremamente carismática e tenha uma história de vida muito semelhante a da maioria dos pentecostais, Marina Silva aderiu ao movimento pentecostal bem depois de ter entrado na política eleitoral e sua agenda política sempre privilegiou os temas relacionados ao meio ambiente. Ou seja, questões mais distantes do imaginário dos segmentos pentecostais que vivem nas periferias das grandes cidades. Além disso, o Partido Verde sempre teve uma plataforma política próxima das demandas dos movimentos feministas e LGBT que são contrárias ao discurso moral e familista dos líderes religiosos tradicionalistas, de modo que as tensões entre os dois campos discursivos não permitiam grandes expectativas de sucesso eleitoral. As declarações do Pastor da Assembleia de Deus, Sóstenes Apolos da Silva, em relação ao partido de sua candidata ilustram bem as dificuldades para ampliar a rede de apoio em torno da candidatura de Marina. Em entrevista concedida à revista Época, o líder espiritual da candidata verde e responsável pela sua campanha entre os evangélicos afirmou:

Sim, havia questões discordantes, como em todo partido. Mas tem de se levar em conta que no Brasil estatuto de partido não vale nada, ideologia não existe. Então há duas coisas: primeiro, a bandeira do partido, do meio ambiente, coincide com a dela. Segundo, aquilo que é contrário aos princípios de Marina, ela se posicionou publicamente e conseguiu que o partido deixasse isso no âmbito de questões de consciência. ${ }^{16}$

Com isso, pode se afirmar que a despeito da afiliação de Marina à Assembleia de Deus, os pastores que efetivamente mais exploraram o imaginário religioso e o discurso moral cristão durante o pleito eleitoral na tentativa de desqualificar a candidatura petista e atrair os votos dos segmentos mais tradicionalistas eram simpatizantes da candidatura de José Serra. Apoiando esse candidato desde o lançamento de sua candidatura pelo PSDB encontrava-se, por exemplo, o presidente da Convenção Geral das Assembleias de Deus do Brasil, o pastor José Wellington Bezerra, que acionou os veículos de comunicação de seu grupo contra o PT e sua candidata.

Outro líder que, depois de uma rápida aproximação com a candidatura de Marina Silva, resolveu apoiar José Serra nas eleições foi o Pastor Silas Malafaia. Importante formador de opinião pública no meio pentecostal do

${ }_{16}$ Ver http://flaviaaleixo.wordpress.com/2010/06/26/o-pastor-evangelico-de-marina-silva/ 
Rio de Janeiro, esse Pastor espalhou na capital do Estado, durante o primeiro turno, 600 outdoors em "favor da família e preservação da espécie humana" e transformou vários trechos de seu programa televisivo "Vitória em Cristo" em vídeos que foram postados no YouTube. Nesses vídeos atacava fortemente o PNDH3, classificado por ele como "Plano Nacional da Vergonha Humana" e alertava aos evangélicos sobre a importância do voto uma vez que as propostas ali inscritas seriam objeto de exame da próxima legislatura e sancionadas e ou vetadas pelo poder executivo. ${ }^{17}$

No segundo turno, o Pastor Malafaia digladiou com o bispo da Igreja Universal nos meios de comunicação, apareceu durante o Horário Gratuito de Propaganda Eleitoral orientando os evangélicos a votarem no candidato do PSDB e distribuiu gratuitamente DVDs com sua declaração de voto entre os frequentadores da Igreja Assembleia de Deus Vitória em Cristo para que difundissem as orientações políticas no grupo familiar.

Além do engajamento desses dois importantes líderes pentecostais na campanha de José Serra, verificou-se na internet a articulação de pastores do segmento mais histórico do protestantismo para combater o programa do PT e as candidaturas desse partido político nas disputas pelos poderes executivo e legislativo. O vídeo postado no YouTube pelo pastor batista Paschoal Piragine Júnior, nos primeiros dias de setembro de 2010, associava as iniciativas dos dois governos Lula com a destruição dos valores cristãos e teve uma grande repercussão dentro e fora da Igreja Batista, que é a segunda denominação evangélica em número de fiéis no Brasil. Vários pastores reproduziram em seus cultos dominicais o vídeo com imagens de fetos sendo agredidos por instrumentos cortantes, e o presidente e o secretário executivo da Ordem dos Pastores Batistas do Brasil (OPBB) endossaram as críticas do pastor Piragine ao $\mathrm{PNDH} 3$ e ao projeto de Lei de $\mathrm{n}^{\circ} 122$, que criminaliza a Homofobia, em nota enviada por e-mail a todos os pastores e posteriormente postada no site da OPBB. ${ }^{18}$

\footnotetext{
7 De acordo com sua perspectiva, a definição do voto deveria levar em conta o alinhamento das posições morais dos candidatos com a dos eleitores; assim, o evangélico que fosse contra o aborto e a união civil entre pessoas do mesmo sexo deveria votar nos candidatos contra as propostas do PNDH3 e do PL 122.

18 Ver a entrevista com o pastor Valdemar Figueiredo Filho no seguinte endereço: http://www.adiberj. org/portal/2010/11/06/qual-o-papel-da-religiao-nas-ultimas-eleicoes/. Ver a nota assinada por Lécio Dornas, Presidente e Juracy Carlos Bahia, Diretor Executivo da OPBB no endereço a seguir.http:// noticiasdabatistadomeier.blogspot.com/2010_09_01_archive.html.
} 
Os efeitos dessa "conversação" intermídias logo seriam detectados pelos institutos de pesquisa que procuravam conhecer a intenção de voto dos brasileiros. Nos surveys realizados até o final do mês de agosto, a preferência religiosa não aparecia como uma variável importante na definição do voto do eleitor. Entretanto, a partir de setembro, os dados começaram a revelar a perda de apoio entre os evangélicos e o crescimento da rejeição de Dilma Rousseff nesse segmento religioso. Em apenas quinze dias, a candidata do PT perdeu sete pontos percentuais nesse grupo, enquanto mantinha-se estável entre os católicos e integrantes de outras confissões religiosas. ${ }^{19}$ Simultaneamente, as intenções de voto de José Serra e Marina Silva começaram a crescer entre os eleitores evangélicos. Enquanto a curva de intenção de votos do peessedebista aumentou dez pontos percentuais entre 2/9/2010 e 16/9/2010, a da candidata do PV ganhou sete pontos percentuais nesse mesmo período de tempo. Essas mudanças no segmento em que se encontravam $20 \%$ dos eleitores brasileiros teriam impacto importante em uma disputa apertada como a eleição presidencial e exigiriam novas tentativas de mobilização dos segmentos evangélicos pró-Dilma no final do primeiro turno das eleições.

No campo católico, alguns líderes conservadores manifestaram-se publicamente contra Dilma e o PT pelas posições do partido em relação ao tema do aborto e receberam apoio do Santo Papa nessa tentativa de interferência no pleito eleitoral. Na realidade, ainda no final de julho de 2010, portanto três meses antes do primeiro turno das eleições, o bispo da Diocese de Guarulhos (SP), D. Luiz Gonzaga Bergonzini, escreveu o artigo "Dai a César o que é de César e a Deus o que é de Deus", que foi publicado na Folha Diocesana de Guarulhos e no site da Conferência Nacional dos Bispos do Brasil (CNBB). Nesse artigo o bispo afirmava ser "dever da Igreja intervir no cenário político-eleitoral" e orientava os fiéis a não votar em partido ou candidato que "desrespeitasse a vida" e os "valores familiares". A polêmica gerada no interior da CNBB acabou fazendo com que o artigo fosse retirado do site da entidade poucos dias depois de sua divulgação e que as divergências entre os bispos começassem a ser mais exploradas pela mídia secular e pelos partidos políticos. Assim, enquanto Dom Bergonzini encabeçava a "cruzada"

\footnotetext{
19 Ver a matéria "A corrida Presidencial de Dilma para recuperar voto evangélico marca a reta final da campanha presidencial", de José Roberto Toledo, no seguinte endereço: http://blogs.estadao.com. br/vox-publica/2010/10/01/corrida-de-dilma-para-recuperar-voto-evangelico-marca-reta-final-da-campanha-presidencial/.
} 
em defesa da vida, mandando imprimir e divulgando mensagens aos fiéis em que apresentava Dilma Rousseff como a "candidata da morte", e-mails eram enviados aos eleitores pelo núcleo da campanha do PT, divulgando a posição favorável de Dom Luís Carlos Eccel ${ }^{20}$, bispo de Santa Catarina, em relação à candidatura de Dilma Rousseff.

Deve-se esclarecer, entretanto, que os grandes veículos de comunicação nacional, preferindo o retorno do PSDB ao poder político, exploraram muito mais os ataques do que as posições favoráveis dos segmentos mais progressistas ao PT e da sua candidata. As mídias digitais dos candidatos do PSDB e do PT tratariam de replicar as matérias escritas, assim como postar os vídeos com declarações favoráveis e contrárias aos dois candidatos nos sites e blogs partidários e compartilhados no YouTube.

No mês de agosto, a Presidência e a Comissão Representativa dos Bispos do Regional Sul 1 da CNBB acolheram e divulgaram o documento intitulado "Apelo a todos os brasileiros e brasileiras", elaborado pela Comissão em Defesa da Vida daquela regional. Em tal documento, depois de listar uma série de compromissos e deliberações do PT no campo dos direitos reprodutivos e da interrupção da gravidez, os bispos recomendavam "a todos os cidadãos e cidadãs" que só votassem em candidatos/as e partidos políticos contrários à descriminalização do aborto. $\mathrm{O}$ objetivo da divulgação era mostrar que Dom Bergonzini não estava sozinho em sua luta contra a candidatura petista, mas acabou por provocar novas manifestações de discordância em relação às orientações traçadas. Uma nota pública das Católicas pelo Direito de Decidir, repudiando veemente a tentativa dos signatários do documento de influenciar o processo e defendendo a laicidade do Estado, serviria de contraponto à jogada ensaiada pelo grupo reunido em torno do bispo de Guarulhos. ${ }^{21}$

Entretanto, no dia 17 de setembro, a Polícia Federal, atendendo uma liminar expedida pelo Tribunal Superior Eleitoral, apreendeu numa gráfica da capital do estado de São Paulo panfletos encomendados pela Diocese de Guarulhos que foram considerados propaganda eleitoral irregular, e essa apreensão trouxe à tona os elos dos atores religiosos conservadores católicos

\footnotetext{
20 Poucos dias depois do $2^{\circ}$ turno, Dom Luís Carlos Eccel renunciaria ao cargo de Bispo, e a mídia atribuiria essa renúncia à pressão do próprio Vaticano descontente com o apoio do Bispo à Dilma. Ver a edição online do Jornal do Brasil, de 24 de novembro de 2010. www.jb.com.br/...papa-aceita-renuncia-de-bispo-brasileiro-que-apoiou-dilma-rousseff/ -

${ }^{21}$ A nota foi publicada em 10 de setembro de 2010.Ver: http://www.viomundo.com.br/blog-da-mulher/ catolicas-pelo-direito-de-decidir-repudiam-nota-da-cnbb.html
} 
com a campanha de José Serra. A empresa responsável pela impressão pertencia aos familiares de um dos coordenadores da campanha do candidato do PSDB e o teor do documento a ser distribuído nos templos era claramente desfavorável à sua adversária Dilma Rousseff.

O grande lance dos católicos conservadores estaria a cargo de Bento XVI, que, aproveitando a visita de um grupo de Bispos do Brasil à Santa Sé, cinco dias antes da realização da primeira rodada eleitoral, enviou uma mensagem aos integrantes do corpo clerical da igreja local pedindo que esclarecessem seus fiéis em relação às posições da Igreja e dos distintos candidatos no que se refere ao aborto e à união civil de pessoas do mesmo sexo. ${ }^{22}$ Esse fato foi amplamente utilizado pela candidatura do PSDB gerando indignação nos defensores da laicidade do Estado e constrangimento entre os católicos progressistas. Nesse sentido, um dia depois da tentativa do Papa de interferir no jogo eleitoral, o sacerdote Gabriel Cipriani, assessor do Conselho de Igrejas Cristãs do Brasil (CONIC), ${ }^{23}$ foi ao "Encontro de Dilma com os cristãos", realizado em Brasília ${ }^{24}$. Afirmando aos órgãos de imprensa estar ali representando o Bispo da Diocese de Jales, Dom Demétrio Valentini, o sacerdote gravou um depoimento ${ }^{25}$ de apoio à Dilma pelo compromisso da candidata com a erradicação da pobreza que atinge grande parte das famílias brasileiras.

Mesmo assim, a queda de Dilma Rousseff que começou entre os evangélicos se estendeu aos católicos na véspera do primeiro turno e, segundo alguns comentaristas, a interferência do Santo Papa só não teve um impacto maior porque sua manifestação ocorreu numa data muito próxima à consulta aos eleitores, o que dificultava a mudança na intenção de votos de um número significativo dos fiéis. De qualquer maneira, o voto religioso jogou um papel decisivo na primeira consulta adiando a vitória da candidata do PT para a segunda fase do processo eleitoral.

\footnotetext{
22 Essa intervenção lembra o que ocorreu em 2007, quando os legisladores da cidade do México aprovaram a lei que descriminalizou o aborto até doze semanas de gestação e despertou uma grande reação da Igreja local e do próprio Papa Bento XVI, que ameaçou excomungar os legisladores responsáveis pela revisão da lei (Blancarte, 2008).

23 O sacerdote atua também no Movimento de Educação de Base (MEB).

24 http://noticias.terra.com.br/eleicoes/2010/noticias/0,_Ol4737646-El15315,00-Liderancas+cristas+dev em+entregar+mensagem+a+Dilma+na+segunda.html.

25 Segundo a mídia, nesse encontro estavam vinte e sete lideranças evangélicas e católicas. Além do sacerdote Gabriel Cipriani, estava no referido encontro o deputado Gabriel Chalita ligado à Renovação Carismática Católica. Ver vídeo do depoimento do sacerdote no seguinte endereço: http://www. youtube.com/watch?v=xwAdlp5GN4c.
} 
Em pesquisa realizada logo depois do primeiro turno eleitoral, o instituto IBOPE aferiu que $61 \%$ do eleitorado brasileiro se declaravam católicos, 19\% evangélicos, 5\% de outras religiões, $10 \%$ se diziam religiosos sem seguir uma igreja e $3 \%$ se identificavam como ateus ${ }^{26}$. Para além da filiação religiosa, verificou-se que $10 \%$ dos eleitores iam diariamente às missas ou cultos, e $35 \%$ ao menos uma vez por semana. E o que mais nos interessa aqui, constatou-se que $2 \%$ do eleitorado receberam orientação dentro da igreja ou templo contra o voto em Dilma no $1^{\circ}$ turno e metade dos que afirmaram afirmativamente declararam que seguiu essa orientação. A mesma pesquisa indicou que a candidata petista teve o voto da metade dos eleitores católicos e de pouco mais de um terço dos evangélicos, segmento em que empatou com o candidato José Serra (PSDB). Já Marina Silva, embora disputando por um partido político pequeno e com pouco tempo de propaganda gratuita na mídia nacional, conseguiria um quarto dos votos dos seus irmãos de fé.

Outro dado significativo revelado por essa enquete é que $80 \%$ dos eleitores brasileiros se posicionavam contra mudanças na legislação do aborto, e o pânico moral criado pelos líderes cristãos repercutiu nas urnas. É bem verdade que as denúncias de corrupção envolvendo a chefe da Casa Civil do governo Lula, Erenice Guerra, cujo nome foi indicado pela própria Dilma Rousseff para aquele posto, vieram à tona nesse mesmo período e, sendo assim, as mudanças nas intenções de voto não podem ser atribuídas unicamente ao ativismo religioso. Contudo, não se pode ignorar o fato de que na data prevista para a realização da pesquisa IBOPE já citada, 13 de outubro de 2010, vários líderes evangélicos foram convidados para uma reunião com a candidata Dilma e o então presidente Lula em Brasília e nessa ocasião exigiram uma nova manifestação pública de que uma vez no poder executivo não encaminharia nenhuma proposta de lei que envolvesse os temas do aborto, da liberdade religiosa e da união civil de pessoas do mesmo sexo. Em 15 de outubro, a petista lançou então "A mensagem de Dilma", reiterando sua posição.

Dirijo-me mais uma vez a vocês, com o carinho e o respeito que merecem os que sonham com um Brasil cada vez mais perto da premissa do Evangelho de desejar ao próximo o que queremos para nós mesmos. É com esta convicção que resolvi pôr

${ }^{26} 2 \%$ não responderam a questão. Ver a matéria "Serra lidera entre os evangélicos", publicada no Jornal O Globo, de 15 de outubro de 2010, p. 9. 
um fim definitivo à campanha de calúnias e boatos espalhados por meus adversários eleitorais. Para não permitir que prevaleça a mentira como arma em busca de votos, em nome da verdade quero reafirmar: 1) Defendo a convivência entre as diferentes religiões e a liberdade religiosa, assegurada pela Constituição Federal; 2) Sou pessoalmente contra o aborto e defendo a manutenção da legislação atual sobre o assunto; 3) Eleita presidente da República, não tomarei a iniciativa de propor alterações de pontos que tratem da legislação do aborto e de outros temas concernentes à família e à livre expressão de qualquer religião no País;4) O PNDH é uma ampla carta de intenções, que incorporou itens do programa anterior. Está sendo revisto e, se eleita, não pretendo promover nenhuma iniciativa que afronte a família; 5) Com relação ao PLC 122, caso aprovado no Senado, onde tramita atualmente, será sancionado em meu futuro governo nos artigos que não violem a liberdade de crença, culto e expressão e demais garantias constitucionais individuais existentes no Brasil [...].

Três dias antes do segundo turno das eleições, uma mensagem do Bispo Carlos Eccel da Diocese de Jales aos eleitores foi postada na rede social criada para apoiar a candidatura de Dilma Rousseff ${ }^{27}$, denunciando "as facções sociais, políticas e religiosas especializadas em fazer lavagem cerebral" que estariam deturpando a preocupação do Santo Papa com a vida humana e seu pronunciamento às vésperas do primeiro turno. Tentando uma releitura da mensagem papal, Dom Carlos Eccel escreveu:

Como bispo da Igreja Católica, e como cidadão brasileiro, fico feliz por saber que nosso Presidente tem defendido a vida, e sempre se pronunciou contra o aborto. Nesses últimos anos o Brasil tem crescido e melhorado em todos os aspectos, de maneira especial no respeito à vida e a valorização da dignidade humana. Esta é a Vontade de Deus! E as pessoas, em plena posse de suas faculdades mentais, vão reconhecer esta verdade. Nosso país está em pleno desenvolvimento e assim queremos continuar e, depois de 500 anos, nosso povo quer eleger, pela primeira vez, uma mulher que tem compromisso com a vida e provou isso com sua própria vida. Como? Ela não fugiu para o exterior durante a ditadura, mas a enfrentou com garra e, por isso, foi presa e torturada. Ela queria um país livre, e que todas as pessoas pudessem viver sem medo de serem felizes, vencendo a mentira e o ódio com a verdade e o amor, servindo aos ideais de liberdade e justiça, com sua própria vida. Disse Jesus: "Ninguém tem maior amor do aquele que dá a própria vida pelos irmãos" (Jo 15,13).

27 http://dilmanarede.com.br/ondavermelha/noticias/o-papa-e-a-politica-por-dom-luiz-carlos-eccel 
Obrigado Santo Padre por suas sábias palavras! A Dilma é a resposta para as nossas inquietações a respeito da vida. Quem sofreu nos porões da ditadura, não mata. Mas teve gente que matou a vida no seu ventre para fugir da ditadura, e portanto não deveria se comportar como os fariseus, que jogam pedras, sabendo-se pecadores. E Jesus disse: "Quem quiser salvar a sua vida vai perdê-la, e quem entregar sua vida por causa de mim, vai salvá-la” (Mt 10,39)

Vamos fazer o nosso Brasil avançar ainda mais, com Dilma, que já provou ser coerente, competente e comprometida com a VIDA. O dragão devastador não pode voltar ao poder.

Uma pesquisa realizada no dia do segundo turno eleitoral pelo IBOPE nos locais de votação e nos domicílios, levantando não só o voto como também a afiliação religiosa, revelou que Dilma venceu por larga margem entre os eleitores católicos (58\%), mas praticamente empatou com o seu adversário entre os evangélicos (52 a 48\% dos votos). Esses resultados confirmam, uma vez mais, a distância dos fiéis católicos em relação às posições do Vaticano nos debates públicos contemporâneos. Nesse ponto, a mensagem do Papa acabou sendo um tiro no pé da própria estrutura eclesiástica que saiu fragmentada e mais fragilizada do processo eleitoral. Os dados demonstram também que parte significativa dos votos dos eleitores evangélicos direcionados para Marina Silva no primeiro turno foi depois canalizada para José Serra e que o apoio de atores religiosos como Edir Macedo, Manoel Ferreira, Magno Malta, entre outros, evitou que a adesão ao candidato do PSDB fosse maior.

\section{A campanha dos atores religiosos no cyber espaço: a disputa pela Câmara Federal em foco}

Mais do que nunca é preciso cuidado nessas próximas eleições. Cuidado com o deputado Federal em que vão votar, cuidado com o deputado estadual e com os senadores em quem vão votar [...].Vê a ideologia deles, vê o que eles defendem[...] Existem leis no Congresso Nacional contra nós para serem votadas. Existem Leis nas Assembleias Legislativas Estaduais contra nós para serem votadas. E são vocês, povo de Deus, povo evangélico que vão decidir como vamos escrever nossa história para a geração futura... (Pastor Silas Malafaia, vídeo no YouTube) ${ }^{28}$

${ }^{28} \mathrm{http}: / /$ www.youtube.com/watch?v=WImKCP351RI\&feature=related. 
Se a mobilização dos atores religiosos no processo majoritário ocorreu em torno dos três principais candidatos, nas disputas proporcionais a competição entre os coletivos religiosos levou ao engajamento nas candidaturas originárias do próprio grupo confessional ou de denominações afins. Embora existissem quatro agremiações partidárias de matriz ideológica cristã - Partido Trabalhista Cristão (PTC); Partido Social Cristão (PSC); o Partido Humanista da Solidariedade (PHS); e Partido Social Democrata Cristão (PSDC) -, as candidaturas para o poder legislativo com vínculos com os movimentos religiosos se distribuíam pelos vinte e sete partidos existentes no país. Nessa sessão irei me concentrar na análise das campanhas para a esfera legislativa federal e mais do que discutir as formas de apoio, examinarei a intermediação da religião na construção das candidaturas e na posição em relação ao tema do aborto. Ou seja, deslocarei o foco do ativismo dos líderes espirituais para o exame do desempenho eleitoral dos candidatos que articulavam o uso da afiliação religiosa e o combate ao aborto para atrair os eleitores nas mídias digitais.

O exame desse material é importante porque no final de abril de 2010, durante o $3^{\circ}$ Encontro de Legisladores e Governantes pela Vida, realizado na Câmara Federal, parlamentares que exerciam mandatos no Congresso Nacional e que integravam a Frente Parlamentar em Defesa da Vida juntamente com o Movimento Nacional da Cidadania pela Vida - O Brasil sem aborto lançaram a campanha "A vida depende de seu voto" - reiteraram a importância das mídias digitais para o processo eleitoral daquele ano. Naquela ocasião, Lenise Garcia, presidente do movimento, afirmou

que o objetivo é obter um compromisso contra o aborto, registrado em cartório, dos candidatos ao Executivo e ao Parlamento, nos níveis federal e estadual. Essas informações serão colocadas na internet, repetindo estratégia adotada em 2006 e 2008 [...], isso é importante porque o aborto tornou-se um tema mundial. "A América Latina vem segurando a 'onda abortista', o que pode permitir ações que façam recuar as leis adotadas em outros países", afirmou Lenise. ${ }^{29}$

Nos meses que se seguiram, listas com nomes de candidatos pró e contra a descriminalização do aborto foram postadas em vários sites ligados aos

${ }^{29}$ http://www2.camara.gov.br/agencia/noticias/DIREITOS-HUMANOS/147159-FRENTE-PARLAMENTAR-CONTRA-O-ABORTO-LANCA-CAMPANHA-PARA-AS-ELEICOES.html 
movimentos em defesa da vida e disparadas em e-mails por diferentes coletivos religiosos, sacerdotes e militantes leigos alertando sobre os riscos de se escolher um representante político que já se havia colocado publicamente a favor da interrupção da gravidez indesejada. Alguns candidatos também explorariam a temática do abortamento em sua campanha digital, mas antes de examinarmos as suas posições precisamos esclarecer como levantamos as informações aqui analisadas ${ }^{30}$.

A amostra que serviu de base para o acompanhamento das candidaturas na internet resultou de um sorteio num universo de candidaturas ${ }^{31}$ distribuídas em quatorze estados das diferentes regiões brasileiras ${ }^{32}$ e dos partidos com representação na Câmara a partir das eleições de $2006^{33}$. A seleção da amostra contemplou também os critérios de equivalência do número de candidatos por sexo e de proporcionalidade no que se refere aos partidos e regiões. De modo que foram sorteados duzentos e sessenta nomes de candidatos e iniciou-se a pesquisa de localização dos sites e blogs dos candidatos na $w e b$. Deve-se esclarecer ainda que foram identificados oitenta e um políticos com sítios na internet, mas só em 32\% dessas mídias foram encontradas as referências religiosas que permitiram a delimitação da configuração dos atores políticos cujas candidaturas serão examinadas nessa sessão do texto. ${ }^{34}$

A leitura do conteúdo dos blogs e sites dos candidatos permitiu identificar menções à religião em vinte mídias digitais de candidatos do sexo masculino e seis do sexo feminino. Essa maior incidência dos homens se deve muito mais à natureza da atividade da representação política do que à capacidade da esfera religiosa de atrair esses atores sociais, uma vez que a literatura especializada

${ }^{30}$ Os dados aqui apresentados resultam de minha inserção no Consórcio Bertha Lutz criado em 2010 para estudar as assimetrias de gênero no processo eleitoral. Esse consórcio foi composto por pesquisadores/ as feministas de várias universidades e centros de pesquisa do Brasil, e a investigação foi financiada pela Secretária de Políticas para as Mulheres, órgão diretamente ligado à Presidência da República.

31 Haviam 4.920 candidatos inscritos. Desse montante, 80, 9\% eram do sexo masculino e 19,1\% do sexo feminino.

32 Todas as unidades federativas do sul e do sudeste brasileiro foram incluídas, já do Nordeste foram pré-selecionados Pernambuco, Sergipe e Bahia, e do Norte os estados do Amapá e do Amazonas.

33 A Câmara Federal é composta por 513 parlamentares.

${ }^{34}$ É preciso informar que posteriormente ao levantamento daqueles que dispunham de mídias digitais para sua campanha, o conteúdo foi gravado, lido e registrado em planilhas individuais que contemplaram os dados básicos de identificação do sítio, os recursos tecnológicos e as referências visuais empregadas, assim como os dados relativos aos candidatos de ambos os sexos - biografia, agenda política, representação de interesses, entre outros. Além dessa primeira visita, os sítios foram monitorados durante a campanha eleitoral através de feeds que facilitaram o acompanhamento das atualizações recebidas automaticamente em e-mails criados especificamente para tal fim. 
demonstra a maior afinidade das mulheres com os grupos confessionais. É importante lembrar também que, a despeito da face feminina da maioria das religiões, o sistema de autoridade dos grupos religiosos tende a privilegiar os homens tanto na ocupação dos cargos eclesiásticos quanto na representação da comunidade confessional na sociedade mais ampla. De qualquer forma, o fato de as mulheres representarem menos de um quarto dos atores com campanha na mídia digital corrobora as teses do gap de gênero em relação aos recursos eleitorais apontadas em investigações anteriores (Araújo, 2007).

A distribuição dos candidatos segundo a filiação religiosa era a seguinte: doze eram católicos, oito eram evangélicos, um candomblecista, um espirita, um mórmon e três, embora adotassem o discurso cristão, não identificavam a denominação religiosa. Quando esses dados foram cotejados com as informações coletadas no survey realizado com os integrantes da amostra sorteada $^{35}$, verificou-se que dezenove outros candidatos tinham vínculos religiosos, embora não explorassem tais vínculos na web, e que, portanto, a dimensão religiosa pode ter um peso maior do que o observado nas duas mídias da internet selecionadas para o monitoramento: os sites e blogs.

Contudo, analisarei prioritariamente as informações dos candidatos que fizeram menção à sua comunidade confessional ou veicularam imagens ou símbolos religiosos nas mídias digitais e só utilizarei de forma complementar os dados do survey. Nesse sentido, cabe lembrar que, seja de forma simbólica ou textual, elementos religiosos foram constados em mais de um terço das mídias citadas anteriormente. A religião foi apresentada tanto nas biografias como um elemento da trajetória de vida e uma atuação social, quanto nos registros textuais e fotográficos de visitas aos líderes religiosos e de participação do político em celebrações que marcam o calendário religioso no país ${ }^{36}$.

É interessante registrar ainda que, apesar de só um pequeno número de entrevistados ter citado a militância em movimentos religiosos, os movimentos indicados não se restringem ao espectro mais conservador. Sete candidatos atuaram nas pastorais e nos movimentos sociais ligados a Igreja Católica, e essa atuação ocorreu em momentos distintos das suas trajetórias políticas.

35 Da amostra sorteada, cento e trinta e quatro candidatos aceitaram participar do survey realizado pelo Consórcio Bertha Lutz.

${ }^{36}$ Um bom exemplo foi a notícia, postada na mídia digital da candidata Maria Dalva Figueiredo, do Partido dos Trabalhadores, de sua participação na tradicional procissão da festa de São Tiago no interior do Estado do Amapá. Observou-se também o uso de orações, frases bíblicas e símbolos religiosos para atrair os internautas eleitores. 
No campo mais tradicionalista, foram identificadas menções ao Movimento de Cursilho da Cristandade, a Pastoral da Família e o "Movimento Católico em Ação", que desenvolve ações assistenciais em comunidades carentes. Já no polo mais progressista foram encontrados registros de participação nos movimentos da Igreja que lutaram contra a ditadura militar, na Ação Católica Operária, nas Comunidades Eclesiais de Base (CEBS), na Comissão Pastoral da Terra (CPT), no Movimento dos Sem Terra (MST) e do Movimento das Mulheres Agricultoras, atualmente Movimento de Mulheres Camponesas.

Deve se assinalar que a despeito dos escândalos envolvendo quadros políticos do PT, esse partido mostrou-se ainda muito atraente aos atores católicos mais progressistas. Ou seja, enquanto os políticos oriundos dos movimentos tradicionalistas se dividiram entre agremiações de centro ou de direita, os candidatos com passagens nos movimentos católicos mais progressistas concentravam-se no PT. Um dos políticos petistas mais expressivos que dispunha de site na web foi Nilmário Miranda, candidato cuja trajetória política incluiu a participação, durante a sua juventude, na Ação Popular Católica de Minas Gerais e que, ao ser entrevistado no survey, declarou ser hoje um católico não praticante ${ }^{37}$. Foi na gestão desse político na Secretária dos Direitos Humanos ${ }^{38}$ do primeiro governo Lula, que foi desenvolvido o Programa Nacional de Combate à Homofobia, iniciativa que lhe rendeu uma grande simpatia nos segmentos LGBT. Durante o período da campanha política, foram localizados no seu blog vários registros de apoio dos militantes dos movimentos pela diversidade sexual à sua candidatura, assim como notícias de sua participação na Parada Gay e outras atividades junto ao público LGBT. O caso desse petista é interessante, pois demonstra as múltiplas possibilidades de articulações da dimensão religiosa com a dimensão política e, portanto, o grau de complexidade do debate atual sobre o ativismo religioso na esfera pública brasileira.

Assim como a maioria dos católicos, os candidatos que assumiram a filiação aos grupos evangélicos também divulgaram na web a participação em eventos e encontros com lideranças e em ações assistenciais realizadas pelas

\footnotetext{
37 Segundo texto do seu blog "a vida política de Nilmário Miranda começou na década de 60, em movimentos ligados à Igreja e ao meio estudantil. Em 1964, chegou a participar de reuniões da Ação Popular, ligada à ala esquerda da Igreja Católica. No ano seguinte, passou a militar na organização revolucionária clandestina Polop (Política Operária)". http://www.blogdonilmario.com.br/conteudo.php?LISTA=menu\&MENU=1er

${ }^{38}$ Ele esteve a frente da Secretária dos Direitos Humanos entre 2003 e 2005.
} 
igrejas. O ator político de nossa amostra que apresentava laços mais estreitos com uma estrutura eclesiástica foi o candidato Marcel Alexandre da Silva que disputava a representação do estado do Amazonas pelo PMDB. Além de pastor da Igreja Ministério Internacional da Restauração, esse candidato era casado com uma bispa de sua denominação, e o lema de sua campanha foi "Fé e trabalho: a força que vem do altar". Em seu blog, foram encontradas citações bíblicas do tipo "Deus constituiu política para a sua própria glória e o bem público". Outros políticos evangélicos também utilizaram o discurso cristão e ou imagens fotográficas de sua presença em celebrações religiosas para legitimar suas candidaturas. $\mathrm{O}$ candidato do Partido Democrático Trabalhista, Luiz Araújo Costa, utilizou o slogan "Deus é fiel, valorize seu voto!" e dirigiu seu discurso aos "Cristãos, baianos e petroleiros". Já o candidato da Igreja Evangélica Ministério da Fé, Virgilio Neto do PSDB do Distrito Federal, relatou em sua biografia que distribui bíblias, colaborou na reconstrução de templos, fez doações para serviços assistenciais de outras igrejas e que possui um centro social com o seu nome: o Instituto Virgilio Neto.

As candidatas evangélicas do Rio de Janeiro, Liliam Sá e Benedita da Silva, e a mórmon de Santa Catarina, Romanna Remor, mencionaram a participação em atividades de organização religiosa que agrega as mulheres a partir de estruturas como a Organização das Moças, na Igreja de Jesus Cristo dos Santos dos Últimos Dias, a Sociedade Auxiliadora Feminina, na Igreja Presbiteriana, e o Chá de Mulheres, na Sociedade Bíblica do Brasil. Além disso, participavam de atividades de cunho assistencial, campanhas para doações e em mutirões que ultrapassam o espaço eclesial. Assim, a candidata Romanna Remor, que disputava pelo Democratas a representação de Santa Catarina, integrava os grupos de voluntários "Mãos que ajudam”, que desenvolve campanhas de doações, e "Eu faço a minha parte", que reforma templos, sendo ambos os movimentos ligados à Igreja de Jesus Cristo dos Santos dos Últimos Dias, da qual a candidata faz parte.

A biografia do candomblecista Emiliano José do PT apresentava textos e fotos de líderes afro-brasileiros que os apoiava, assim como, registros de suas visitas aos terreiros da Bahia. No texto de apresentação de sua biografia política, o candidato afirmava que tem procurado sempre representar “o candomblé nos meus mandatos parlamentares e quero prosseguir com isso". Mesmo entre os candidatos que não citaram o nome de seus grupos confessionais na internet, observou-se a utilização de símbolos, citações 
bíblicas, orações e críticas aos religiosos mais liberais. Pablio Rebessi do PMDB do estado de São Paulo ilustrou todas as páginas do seu blog com uma vela acesa com a inscrição "Deus acima de tudo". Rogério Farah (PT/MG) se apresentou como: "filho da Luz, herdeiro da graça e fruto do amor, sou, por tudo isso, um apaixonado pela vida!", e veiculou orações agradecendo a Deus pela recuperação de sua saúde, pelo desempenho na campanha e pela oração dos internautas.

È importante registrar ainda que, embora as candidaturas masculinas tenham enfatizado mais a dimensão religião na web do que as candidaturas femininas, os dados do survey revelaram que a metade das mulheres recebeu apoio de igrejas na competição legislativa. As católicas praticantes Rebecca Martins Garcia, Partido Progressista do Amazonas, e América Tereza Nascimento da Silva, do PMDB do Rio de Janeiro, bem como a mormon Romanna Giulia Remor (DEM/SC) declararam que contaram com o apoio de membros de igrejas no comitê eleitoral e no trabalho de corpo a corpo junto aos eleitores. Além desse tipo de contribuição, pelo menos uma candidata, Marina Pignatario Santana, PT de Goiás, admitiu ter feito curso de formação política na Igreja Católica.

Deve-se mencionar também que, apesar da temática do aborto ter sido fortemente utilizada pelos grupos religiosos na campanha para a Presidência da República, só um quinto dos candidatos religiosos à Câmara Federal que foram monitorados apresentaram suas opiniões em suas mídias. O mais importante quadro do $\mathrm{PT}$ que assumiu sua divergência em relação às propostas do PNDH3 referentes ao tema foi André Vargas, político que disputava a reeleição para representar o estado do Paraná na Câmara Federal. No blog desse parlamentar, o texto de apresentação enfatizava a "atuação destacada na Frente Parlamentar em Defesa da Vida” na legislação anterior (2006-2001). Além dessa menção, observou-se a preocupação do candidato de registrar suas posições pessoais em relação ao embate em torno do tema e os encontros com as lideranças religiosas no período eleitoral. Poucos dias antes da primeira rodada eleitoral, foi postado em seu blog declarações do próprio político de que o partido não punia os filiados contrários à legalização do aborto. Segundo suas palavras, 
contra a legalização, fui presidente do PT do Paraná por sete anos e hoje ocupo um cargo na direção nacional. Não há punição para quem tem posicionamento pessoal contrário.

Com esse tipo de esclarecimento, o político tentava conter a forte campanha contra os candidatos do Partido dos Trabalhadores, deflagrada em seu estado de origem pelo já citado Pastor Piragine. Em vídeo divulgado no You Tube, o pastor lembrava aos eleitores que o partido "havia expulsado" dois parlamentares ligados à Igreja Católica por suas posições contrárias às mudanças na legislação referente ao aborto. A menção à $\mathrm{CNBB}$ e aos então parlamentares Henrique Afonso (AC) e Luiz Bassuma (BA) - esse último, dirigente da Frente Parlamentar em Defesa da Vida durante vários anos -favorecia o uso do vídeo para além das mídias evangélicas e poderia comprometer seriamente as candidaturas petistas caso essas não reagissem ao ativismo conservador.

Observou-se, entretanto, que as manifestações contrárias à proposta de descriminalização do aborto foram mais frequentes nas candidaturas vinculadas aos partidos de centro e de direita. O candidato Lázaro Adelmo Mendonça, do PMDB de Goiás, se apresentava aos eleitores da seguinte forma na página inicial do seu blog: “(A)dvogado - Ética na política; (B) ancário - pela aprovação do PL 512; (C)atólico - contra o aborto". O site do candidato Thiago Matias, do DEM de Goiás, divulgou a seguinte declaração: "assumi desde o primeiro dia de campanha o compromisso na defesa da vida. $E$ isso não tem nada a ver com política. Essa é a posição que sempre defendi e quem me conhece sabe". No final da declaração, este candidato, fornecia o link para o site Brasil sem aborto que divulgava a lista dos "candidatos que se comprometeram com a defesa da vida”. Já o blog da candidata Rosangela Lima Rocha, do PMDB da Bahia, trazia orações para os eleitores e criticas a CNBB, a Teologia da Libertação, aos pastores evangélicos, bem como à discussão do aborto e o apoio de líderes religiosos a candidatos. De acordo com o texto, os eleitores devem lembrar que,

[...] Jesus é meu Deus e só votarei num político que respeite as atribuições que Deus deu ao Estado. [...]. Enquanto Deus criou a vida e o casamento natural, o Estado baalista criou o aborto legal e o antinatural "casamento" homossexual. [...]. O Estado laico, em toda a sua arrogância laica, estabelece que toda atividade e expressão de Deus seja confinada às quatro paredes dos templos religiosos e às quatro paredes dos 
lares dos religiosos. Entretanto, o Estado laico estabelece somente para si direitos e liberdade de atividade e expressão na esfera política e social - inclusive para grupos religiosamente humanistas, abortistas, homossexualistas, ocultistas, socialistas, etc.

Cabe registrar que metade das candidaturas dos atores religiosos monitorados na web foi eleita. E ainda que, em nosso país, a eleição de um candidato não depende exclusivamente do seu desempenho nas urnas, pois deve se considerar o coeficiente eleitoral dos partidos ${ }^{39}$, não se pode ignorar a importância da filiação religiosa na constituição da biografia política e na performance desses atores. Segundo os dados do DIAP (2010), foram eleitos sessenta e três candidatos ${ }^{40}$ vinculados às igrejas evangélicas e quase duas dezenas desses parlamentares têm ou tiveram cargos nas estruturas eclesiásticas como bispos, pastores, diáconos e missionários ${ }^{41}$. Os grupos desse segmento do cristianismo com maior representação na Câmara Federal são justamente os pentecostais que combateram e combatem o PNDH3 e o Plano Nacional de Combate à Homofobia.

Vários artigos ${ }^{42}$ já analisaram como o capital religioso se transforma em capital político e quais são as consequências desse deslizamento entre as fronteiras das esferas política e religiosa para os atores individuais (candidatos e parlamentares) e coletivos (igrejas e entidades supradenominacionais). Aqui, interessa-me assinalar que os evangélicos representam pouco mais de $12 \%$ dos parlamentares com assento na Câmara Federal, portanto, não se pode atribuir a eles toda a responsabilidade pelas dificuldades de ampliação dos direitos sexuais e reprodutivos. A Frente Parlamentar Pela Vida com atuação no Congresso Nacional é composta por políticos das mais diferentes tradições religiosas, alguns deles com trajetória política construída no Partido dos Trabalhadores e junto aos movimentos sindicais e de combate ao autoritarismo. A atuação desse coletivo expressa tensões e controversas

\footnotetext{
39 Segundo Neto (2010),"[...] cada partido ou coligação partidária conquistará, proporcionalmente à soma dos votos obtidos pela legenda e por todos os seus candidatos somados, um determinado número de cadeiras em disputa, privilegiando a ampliação da representação das mais diversas correntes políticas e ideológicas existentes na sociedade." Ver www.faculdadebaianadedireito.com/.../\%7BC11A60F22D67-4D50-8D8B-

40 Pelo menos trinta e dois desse subconjunto de deputados já exerciam mandato naquela casa legislativa.

${ }^{41}$ Bispo Márcio Marinho; Bispo Antônio Bulhões; Pr. João Campos; Pr. Pedro Ribeiro; Pr. Heleno; Pr. Eurico; Pr. Marco Feliciano; Pr. Paulo Freire; Pr. Henrique Afonso; Pr. Silas Câmara; Pr. Josue Bengton; Pr. Jefferson Campos; PrTakayama; Pr. Ronaldo Fonseca;Pr. Roberto Lucena; Missionário Olimpio; Diácono Erivelton Santana; Diácono André Zacharow. (DIAP, 2010)

42 Ver, por exemplo: Oro (2004; 2002); Machado (2006).
} 
em curso na sociedade mais ampla, o que faz com que qualquer tentativa de modificação da legislação existente no campo da moralidade sexual e do aborto exija uma grande capacidade de mobilização dos atores políticos favoráveis à descriminalização do aborto.

\section{Considerações finais}

A participação de atores religiosos individuais e coletivos no pleito eleitoral de 2010, a despeito das especificidades da política institucional e da cultura brasileira, expressa tendências em curso em outras configurações nacionais da América Latina, como: a inclusão dos temas do aborto e da diversidade sexual na agenda pública a partir da atuação dos movimentos feministas e LGBT, o surgimento de novas formas de ativismo religioso, articulando líderes religiosos e ONGs na defesa da ordem sexual e social tradicional e a judicialização dos conflitos sociais ${ }^{43}$. Sinteticamente, pode-se argumentar que, para além da competição interna na esfera religiosa, em especial entre o catolicismo e o pentecostalismo, verifica-se neste início de século uma acirrada disputa de sentidos em torno da vida e da sexualidade humana entre as ideologias de matriz cristã e as de caráter secular, como as dos movimentos feministas e pela diversidade sexual, intensificando-se as demandas pela laicidade do Estado.

A politização do religioso não é propriamente uma novidade na história brasileira e, para não ter que retroceder muito no tempo, basta citar a importante contribuição dos segmentos católicos ligados à Teologia da Libertação, às CEBs e à Pastoral da Terra na mobilização dos segmentos populares em apoio ao PT nos anos 80 e 90. Assim sendo, o que se percebeu nesse último pleito foi a reconfiguração da política dos segmentos religiosos e, mais especificamente, a politização reativa à agenda dos movimentos feministas e LGBT. Nesse processo de reconfiguração, observa-se a mobilização do laicato organizado em movimentos como o Movimento Nacional pela Cidadania Brasil sem Aborto e a Renovação Carismática com o intuito de pressionar os legisladores e conservar as construções legais no campo da moral familiar e sexual. Verifica-se ainda que, enquanto a Igreja Católica desaconselha a participação de seus sacerdotes e freiras nas disputas eleitorais, os grupos pentecostais estimulam os seus quadros - bispos, pastores, diáconos, etc. -

${ }_{43}$ Ver Vaggione (2010); Barretos (2008); Blancarte (2008); Lanza (2008); Mundigo (2005); Reys (2008); Villanueva (2008); Machado e Delvalhas (2011). 
para essas disputas com intuito de ocupar as cadeiras nas casas legislativas e poder influenciar na legislação e nas políticas públicas.

Nesse sentido, se por um lado a crescente competição das igrejas cristãs por fiéis, pelas parcerias com as agências governamentais no campo da ação social e pelas concessões dos meios de comunicação abrem brechas para alianças conjunturais nos pleitos eleitorais com candidatos e partidos políticos mais alinhados com os princípios dos direitos humanos, por outro lado, o apoio eleitoral dos segmentos cristãos que tentam abalar a hegemonia da Igreja Católica, podem comprometer esses mesmos atores com outros temas da agenda religiosa que são nocivos à laicidade do Estado.

Os primeiros meses do governo Dilma demonstraram ainda que a competição entre os grupos religiosos não inviabiliza as ações conjuntas dos segmentos mais tradicionalistas no Congresso Nacional brasileiro na tentativa de barrar as propostas que expressam a constituição de uma moral sexual de caráter secular. No início de março de 2011, o Movimento Nacional Cidadania pela Vida promoveu um café da manhã na Câmara dos Deputados, para apresentar as atividades do movimento em defesa da vida, e partilhar com os deputados federais iniciativas e propostas de ação para a $54^{\text {a }}$ legislatura. Segundo os organizadores, doze deputados federais participaram desse evento e se comprometeram "a dar continuidade à luta contra a legalização do aborto ${ }^{44 "}$. O passo seguinte seria a organização no final de abril, na mesma Câmara dos Deputados, do IV Encontro Brasileiro de Governantes e Legisladores pela Vida, promovido pela Frente Parlamentar da Vida contra o Aborto. No evento, cuja mesa de abertura contava com a presença do deputado Federal Odair Cunha, do PT de Minas Gerais e membro da Renovação Carismática Católica, foi divulgado não só a adesão de 205 parlamentares da nova legislatura nesta Frente ${ }^{45}$, como também o apoio desse coletivo ao Programa Rede Cegonha do Ministério da Saúde. De acordo com Jaime Ferreira Lopes secretário-executivo daquele coletivo,

\footnotetext{
${ }^{44}$ Alberto Filho (PMDB/MA), Salvador Zimbaldi (PDT/SP), Áureo Lírio (PRTB/RJ), João Campos-PSDB/ GO, Gonzaga Patriota-PSB/PE, Pe. José Linhares (PR/CE), Roberto de Lucena (PV/SP), Jorge Tadeu Mudallen (DEM/SP), Manato (PDT/ES), Solange Almeida (PMDB/RJ) Ronaldo Fonseca (PR/DF) e Eros Biondini (PTB/MG).Ver http://vidafamiliaepaz.wordpress.com/2011/03/12/frente-parlamentar-mista-em-defesa-da-vida/

45 Se considerarmos que onze que ali foram mencionados exerciam o mandato de Senadores da República, a percentagem dos políticos com assento na Câmara Federal que teriam uma posição desfavorável ao aborto e militariam na Frente seria de 38\%.
} 
a Frente Parlamentar da Vida Contra o Aborto decidiu na semana passada apoiar o Programa Rede Cegonha [...] por entender que os princípios dele coincidem com os princípios que a frente defende de defesa da vida, de apoio às políticas públicas de apoio à maternidade, que é o centro deste programa. ${ }^{46}$

Considerado por setores feministas como uma iniciativa que reforça a ideologia familista e as representações tradicionais de gênero ${ }^{47}$, esse programa foi lançado apenas três meses depois da posse da primeira mulher na Presidência da República numa clara demonstração de que as políticas reprodutivas continuam fortemente demarcadas pela correlação de forças no interior do campo religioso e das alianças políticas das estruturas eclesiásticas com o Estado e os atores da sociedade civil. De modo que a ampliação dos direitos humanos requer, por um lado, o reconhecimento da razão pública por parte dos atores religiosos, por outro o fortalecimento da cultura da laicidade nas instituições políticas e o aprofundamento do espirito republicano por parte dos governantes.

\section{Referências bibliográficas}

ARAÚJO, Clara. 2007. "Mídia legitimidade eleitoral e mulheres na política". Interseções, ano 9, n. 2, p. 365-395.

AVILA, Maria Betania; PORTELLA, Ana Paula \& FERREIRA, Veronica (orgs.). 2005. Novas legalidades e democratização da vida social: família, sexualidade e aborto. Rio de Janeiro: Garamond.

BARRETOS, Martín Jaime. 2008. "Entre la iglesia católica y el Estado: una mirada a la comunidad política desde el deseo". In: LIENDO, George.; BARRIENTOS, Violeta \& HUACO, Marco (eds.). Memorias del primer

\footnotetext{
${ }^{46}$ http://www.viomundo.com.br/voce-escreve/rede-cegonha-recebe-apoio-da-frente-parlamentar-contra-o-aborto.html

${ }^{47}$ Em entrevista ao site Viamundo, Telia Negrão, secretária-executiva da Rede Nacional Feminista de Saúde, Direitos Sexuais e Direitos Reprodutivos e diretora da RSMLAC afirmou que "o conceito trazido pela Rede Cegonha é um retrocesso nas políticas com enfoque de gênero, saúde integral da mulher e direitos reprodutivos e sexuais". Na mesma direção, a farmacêutica Clair Castilhos, professora do Departamento de Saúde Pública da Universidade Federal de Santa Catarina (UFSC) declarou ao site: "As cegonhas vão parir. ..tudo está resolvido![...] É profundamente doloroso que tenhamos que criticar a formulação e implantação de um programa do Ministério da Saúde voltado para nós mulheres. E o mais irônico e melancólico é que isto aconteça precisamente no momento em que temos um governo presidido por uma mulher com valorosa e digna trajetória política." Ver http://www.viomundo.com. br/entrevistas/rede-feminista-de-saude-rede-cegonha-e-um-retrocesso-de-30-anos-nas-politicas-de-genero-saude-da-mulher-direitos-reprodutivos-e-sexuais.html
} 
seminario internacional fomentando las libertades laicas. Lima: Universidad Nacional Mayor de San Marcos/ Liberdades Laicas- Perú.

BERGER, Peter; DAVIE, Grace \& FOKAS, Effie. 2008. Religious America, secular Europe? A theme and variations. Burlington: Ashagate Publishing Company.

BLANCARTE, Roberto. 2008. "El porque de un Estado laico". In: LIENDO, George.; BARRIENTOS, Violeta \& HUACO, Marco (eds.). Memorias del Primer Seminario Internacional Fomentando las Libertades Laicas. Lima: Universidad Nacional Mayor de San Marcos: Liberdades Laicas- Perú. DIAP. Deputados novos e reeleitos. Disponível em: http://www.diap.org.br/ images/stories/novos-reeleitos-final.pdf. Acesso em 13/12/2010.

DUARTE, Luiz Fernando D.; GOMES, Edlaine C.; MENEZES, Rachel A. \& NATIVIDADE, Marcelo (orgs.). 2009. Valores religiosos e legislação no Brasil. Rio de Janeiro: Garamond.

EISENSTADT, Shmuel N. 2001. "Modernidades múltiplas”. Sociologias, n.35, p.139-163.

GOMES, Edilaine de Campos. 2009. "Fé racional e abundância: familia e aborto a partir da ótica da Igreja Universal do Reino de Deus". Sexualidad, Salud y Sociedad, n. 2, p. 97-120.

GOMES, Edilaine de Campos \& MENEZES, Rachel Aisengart. 2008. "Aborto e eutanasia: dilemas contemporâneos sobre os limites da vida”. Physis, v. 18, n. 1, p. 77-103.

HABERMAS, Jürgen. 2007. Entre o naturalismo e religião. Rio de Janeiro: Tempo Brasileiro.

LANZA, Teresa. 2008. "Situación de los derechos sexuales y reproductivos en Bolivia”. In: LIENDO, George.; BARRIENTOS, Violeta \& HUACO, Marco (eds.). Memorias del Primer Seminario Internacional Fomentando las Libertades Laicas. Lima: Universidad Nacional Mayor de San Marcos/ Liberdades Laicas- Perú.

MACHADO, Maria das Dores C. 2000 "O tema do aborto na mídia pentecostal”. Revista Estudos Feministas, v. 8, p. 200-211.

. 2006. Política e religião. Rio de Janeiro: Fundação Getúlio Vargas. 2010. "Igrejas cristãs e os desafios da ampliação direitos dos humanos na América Latina”. Revista Praia Vermelha, v. 20, p. 157-167.

\& DELVALHAS, Fernanda P. (orgs.). 2011. Religião e homossexualidades. Rio de Janeiro: Fundação Getúlio Vargas. 
MUNDIGO, Axel I. 2005. "Religión y salud reproductiva:encrucijadas y conflictos". Trabalho apresentado na II Reunión de Investigación sobre Embarazo No Deseado y Aborto Inseguro. México, 17 a 19 de agosto. Ver http://www.despenalizacion.org.ar/pdf/publicaciones/Religion_y_salud_reproductiva_encrucijadas_conflictos.pdf.

NETO, Jaime Barreiros "Coeficiente eleitoral: como são eleitos os deputados e vereadores no Brasil". Ver: http://xeque-mate-noticias.blogspot. com/2010/09/voto-em-branconulo-e-de-protesto-saiba.html. Acesso em $23 / 01 / 2012$.

ORO, Ari Pedro. 2002. "A política da igreja universal e seus reflexos nos campos religiosos e políticos brasileiros". Trabalho apresentado no XXVI Encontro Anual da ANPOCS. Caxambu, 22 a 26 de outubro.

. 2004. "Religiões e eleições em Porto Alegre: um comparativo entre 2000 e 2004". Debates do NER, ano 5, n. 6, p. 9-34.

PIERUCCI, Antônio Flávio. 2011. "Eleição 2010: desmoralização eleitoral do moralismo religioso". Novos Estudos Cebrap, n. 89, p. 5-15.

REYS, Marcela Soto. 2008. "Estado laico, iglesia católica y sociedad civil: debates y controversias en torno a la salud y los DSR en la democracia chilena (1990-2005)". In: LIENDO, George.; BARRIENTOS, Violeta \& HUACO, Marco (eds.). Memorias del primer seminario internacional fomentando las libertades laicas. Lima: Universidad Nacional Mayor de San Marcos/ Liberdades Laicas- Perú.

SANTOS, Boaventura de Souza. 2009. "If god were a human rigths activist: human rights and the challenge of political theologies". Law, social, justice global development. Ver: http://www2.warwick.ac.uk/fac/soc/law/ elj/lgd/2009_1/santos.

VAGGIONE, Juan Marco. 2010. “Desplazamientos estratégicos: reconfiguraciones políticas del activismo religioso conservador”. Trabalho apresentado no Seminário Religião e Cultura na América Latina. Rio de Janeiro, agosto de 2010.

VILLANUEVA, Rocío. 2008. "Situación de los derechos sexuales y reproductivos en Perú”. In: LIENDO, George.; BARRIENTOS, Violeta \& HUACO, Marco (eds.). Memorias del Primer Seminario Internacional Fomentando las Libertades Laicas. Lima: Universidad Nacional Mayor de San Marcos: Liberdades Laicas- Perú. 


\title{
Resumo
}

Trata-se de uma análise do ativismo religioso e da inclusão do tema do aborto no debate eleitoral de 2010. Com intuito de examinar as ações coletivas e individuais dos atores religiosos nas disputas tanto pelo executivo quanto pelo legislativo, o artigo foi organizado em três sessões, iniciando-se pela análise das manobras realizadas pelos grupos conservadores da Igreja Católica e dos segmentos evangélicos para interferir na disputa presidencial. Em seguida, são examinadas as campanhas eleitorais de candidatos oriundos do campo religioso à Câmara Federal na webesfera e a importância da dimensão religiosa nas biografias e performances políticas desses atores individuais. Na terceira sessão e à guisa de conclusão, procuram-se estabelecer as conexões entre os projetos políticos individuais e coletivos e demonstrar o caráter reativo do "ativismo religioso conservador" em relação aos avanços dos movimentos no campo feminista e da diversidade sexual no país. Palavras-chave: aborto; religião; eleições.

\begin{abstract}
This is an analysis of religious activism and the inclusion of abortion in the 2010 electoral debate. In order to examine the collective and individual actions of religious actors in both Executive and Legislative disputes, the article is organized in three sections, starting with the analysis of the maneuvers by Catholic and Protestant conservative groups to interfere in the presidential race. Next, it examines electoral campaigns of candidates from the religious field to the Federal Chamber in the Websphere and the importance of the religious dimension in the biographies and political performances of those individual actors. In the third section and as a conclusion, the article establishes connections between individual and collective political projects and demonstrates the reactive nature of "Conservative Religious Activism" towards advances of the movements in the field of feminism and of sexual diversity in the country.
\end{abstract}

Key words: abortion; religion; elections.

Recebido em junho de 2011.

Aprovado em setembro de 2011. 